\title{
2,3,4,5,6,7-Hexahydro-9,10-dimethoxy-1,2-benzothiazonin-3-one 1,1-dioxide
}

Linden, Anthony ; Todorova, Tonya R ; Heimgartner, Heinz

\begin{abstract}
The amide group in the nine-membered ring of the title compound, C13H17NO5S, has the trans conformation. The molecules are linked into infinite one-dimensional chains by bifurcated intermolecular N-H...O hydrogen bonds involving the amide $\mathrm{O}$ atom and one of the sulfonyl $\mathrm{O}$ atoms of the same neigh- bouring molecule. The compound was prepared by the Friedel-Crafts acylation of 1,2dimethoxybenzene and glutaric acid anhydride, followed by reduction of the aryl ketone, esterification, chlorosulfonation, treatment with ammonia, saponification and cyclization of the corresponding 5-(2sulfamoylphenyl)butanoic acid.
\end{abstract}

DOI: https://doi.org/10.1107/S0108270199007489

Posted at the Zurich Open Repository and Archive, University of Zurich ZORA URL: https://doi.org/10.5167/uzh-84356

Journal Article

Published Version

Originally published at:

Linden, Anthony; Todorova, Tonya R; Heimgartner, Heinz (1999). 2,3,4,5,6,7-Hexahydro-9,10-dimethoxy1,2-benzothiazonin-3-one 1,1-dioxide. Acta Crystallographica. Section C: Crystal Structure Communications, 55:1375-137.

DOI: https://doi.org/10.1107/S0108270199007489 
$S=1.037$

5619 reflections

253 parameters

$\mathrm{H}$-atom parameters constrained
$\Delta \rho_{\max }=0.20{\mathrm{e} \AA^{-3}}^{-3}$

$\Delta \rho_{\min }=-0.21{\mathrm{e} \AA^{-3}}^{-3}$

Extinction correction: none

Scattering factors from International Tables for Crystallography (Vol. C)

Table 1. Selected geometric parameters $\left(\AA,^{\circ}\right)$

\begin{tabular}{|c|c|c|c|}
\hline $\mathrm{S} 1-\mathrm{O} 3$ & $1.4250(14)$ & $\mathrm{N} 2^{\prime}-\mathrm{C} 3^{\prime}$ & $1.262(3)$ \\
\hline $\mathrm{S} 1-\mathrm{O} 2$ & $1.439(2)$ & $\mathrm{N} 3-\mathrm{C} 2$ & $1.482(2)$ \\
\hline $\mathrm{S} 1-\mathrm{N} 3$ & $1.628(2)$ & $\mathrm{N} 3-\mathrm{C} 4$ & $1.497(2)$ \\
\hline $\mathrm{S} 1-\mathrm{C} 11$ & $1.759(2)$ & $\mathrm{C} 2-\mathrm{C} 5^{\prime}$ & $1.518(3)$ \\
\hline $\mathrm{O} 1-\mathrm{C} 2$ & $1.402(2)$ & $\mathrm{C} 3^{\prime}-\mathrm{C} 4^{\prime}$ & $1.478(3)$ \\
\hline $\mathrm{O} 1-\mathrm{C} 5$ & $1.427(2)$ & $\mathrm{C} 4-\mathrm{C} 5$ & $1.538(3)$ \\
\hline $\mathrm{Ol}^{\prime}-\mathrm{N} 2^{\prime}$ & $1.428(2)$ & $\mathrm{C} 4^{\prime}-\mathrm{C}^{\prime}$ & $1.514(3)$ \\
\hline $\mathrm{Ol}^{\prime}-\mathrm{C5}^{\prime}$ & $1.444(2)$ & & \\
\hline $\mathrm{O} 3-\mathrm{S} 1-\mathrm{O} 2$ & $120.95(9)$ & $\mathrm{O} 1-\mathrm{C} 2-\mathrm{C}^{\prime}$ & $110.08(15)$ \\
\hline $\mathrm{O} 3-\mathrm{S} 1-\mathrm{N} 3$ & $106.73(9)$ & N3-C2-C5 & $113.20(15)$ \\
\hline $\mathrm{O} 2-\mathrm{S} 1-\mathrm{N} 3$ & $105.49(9)$ & $\mathrm{N} 2^{\prime}-\mathrm{C} 3^{\prime}-\mathrm{C} 4^{\prime}$ & $115.7(2)$ \\
\hline $\mathrm{O} 3-\mathrm{S} 1-\mathrm{C} 11$ & $108.08(9)$ & $\mathrm{N} 2^{\prime}-\mathrm{C} 3^{\prime}-\mathrm{C} 31$ & $120.4(2)$ \\
\hline $\mathrm{O} 2-\mathrm{S} 1-\mathrm{C} 11$ & $106.84(10)$ & $\mathrm{C} 4^{\prime}-\mathrm{C} 3^{\prime}-\mathrm{C} 31$ & $123.9(2)$ \\
\hline N3-S1-C11 & $108.21(9)$ & $\mathrm{N} 3-\mathrm{C} 4-\mathrm{C} 41$ & $110.2(2)$ \\
\hline $\mathrm{C} 2-\mathrm{OI}-\mathrm{C} 5$ & $105.87(13)$ & $\mathrm{N} 3-\mathrm{C} 4-\mathrm{C} 5$ & $100.45(14)$ \\
\hline $\mathrm{N} 2^{\prime}-\mathrm{O}^{\prime}-\mathrm{C} 5^{\prime}$ & $109.16(14)$ & $\mathrm{C}^{\prime}-\mathrm{C} 4^{\prime}-\mathrm{C} 5^{\prime}$ & $100.8(2)$ \\
\hline $\mathrm{C}^{\prime}-\mathrm{N} 2^{\prime}-\mathrm{O} 1^{\prime}$ & $108.0(2)$ & $\mathrm{O} 1-\mathrm{C} 5-\mathrm{C} 4$ & $103.08(14)$ \\
\hline $\mathrm{C} 2-\mathrm{N} 3-\mathrm{C} 4$ & $108.23(13)$ & $\mathrm{O}^{\prime}-\mathrm{C}^{\prime}-\mathrm{C} 4^{\prime}$ & $104.9(2)$ \\
\hline $\mathrm{C} 2-\mathrm{N} 3-\mathrm{S} 1$ & $119.65(11)$ & $\mathrm{Ol}^{\prime}-\mathrm{C} 5^{\prime}-\mathrm{C} 2$ & $107.54(15$ \\
\hline $\mathrm{C} 4-\mathrm{N} 3-\mathrm{S} 1$ & $119.92(12)$ & $\mathrm{C} 4^{\prime}-\mathrm{C}^{\prime}-\mathrm{C} 2$ & $114.9(2)$ \\
\hline $\mathrm{O}-\mathrm{C} 2-\mathrm{N} 3$ & $104.14(13)$ & & \\
\hline \multicolumn{2}{|c|}{$\mathrm{C}^{\prime}-\mathrm{O} 1^{\prime}-\mathrm{N} 2^{\prime}-\mathrm{C} 3^{\prime}$} & \multicolumn{2}{|c|}{$8.2(2)$} \\
\hline \multirow{2}{*}{\multicolumn{2}{|c|}{$\mathrm{C} 5-\mathrm{O} 1-\mathrm{C} 2-\mathrm{N} 3$}} & \multicolumn{2}{|c|}{$-37.0(2)$} \\
\hline \multirow{2}{*}{\multicolumn{2}{|c|}{$\mathrm{C} 5-\mathrm{Ol}-\mathrm{C} 2-\mathrm{C}^{\prime}$}} & \multicolumn{2}{|c|}{$-158.67(15)$} \\
\hline & & \multicolumn{2}{|c|}{$15.1(2)$} \\
\hline \multicolumn{2}{|c|}{$\mathrm{C} 4-\mathrm{N} 3-\mathrm{C} 2-\mathrm{C}^{\prime}$} & \multirow{2}{*}{\multicolumn{2}{|c|}{134.7 (2) }} \\
\hline \multicolumn{2}{|c|}{$\mathrm{O}^{\prime}-\mathrm{N} 2^{\prime}-\mathrm{C}^{\prime}-\mathrm{C}^{\prime}$} & $-0.3(2)$ & \\
\hline \multicolumn{2}{|c|}{$\mathrm{C} 2-\mathrm{N} 3-\mathrm{C} 4-\mathrm{C} 41$} & \multicolumn{2}{|c|}{$-112.3(2)$} \\
\hline \multicolumn{2}{|c|}{$\mathrm{C} 2-\mathrm{N} 3-\mathrm{C} 4-\mathrm{C} 5$} & \multicolumn{2}{|c|}{$10.4(2)$} \\
\hline \multicolumn{2}{|c|}{$\mathrm{N} 2^{\prime}-\mathrm{C}^{\prime}-\mathrm{C}^{\prime}-\mathrm{C}^{\prime}$} & \multicolumn{2}{|c|}{$-7.1(2)$} \\
\hline \multicolumn{2}{|c|}{$\mathrm{C} 2-\mathrm{Ol}-\mathrm{C} 5-\mathrm{C} 4$} & \multirow{2}{*}{\multicolumn{2}{|c|}{$\begin{array}{r}44.2(2) \\
-330(2)\end{array}$}} \\
\hline \multicolumn{2}{|c|}{$\mathrm{N} 3-\mathrm{C} 4-\mathrm{C} 5-\mathrm{O} 1$} & & \\
\hline \multicolumn{2}{|c|}{$\mathrm{C} 41-\mathrm{C} 4-\mathrm{C} 5-\mathrm{Ol}$} & \multirow{2}{*}{\multicolumn{2}{|c|}{$\begin{array}{r}86.6(2) \\
-12.2(2)\end{array}$}} \\
\hline \multicolumn{2}{|c|}{$\mathrm{N} 2^{\prime}-\mathrm{O}^{\prime}-\mathrm{C}^{\prime}-\mathrm{C}^{\prime}$} & & \\
\hline \multicolumn{2}{|c|}{$\mathrm{N} 2^{\prime}-\mathrm{O}^{\prime}-\mathrm{C}^{\prime}-\mathrm{C} 2$} & \multicolumn{2}{|c|}{$110.5(2)$} \\
\hline \multicolumn{2}{|c|}{$\mathrm{C} 3^{\prime}-\mathrm{C}^{\prime}-\mathrm{C}^{\prime}-\mathrm{O}^{\prime}$} & & \\
\hline & $\mathrm{C}^{\prime}-\mathrm{C} 2$ & -1 & \\
\hline & $5^{\prime}-\mathrm{Ol}^{\prime}$ & & \\
\hline & $5^{\prime}-\mathrm{Ol}^{\prime}$ & & \\
\hline & $5^{\prime}-C 4^{\prime}$ & & \\
\hline & $5^{\prime}-\mathrm{C} 4^{\prime}$ & & \\
\hline
\end{tabular}

The $\mathrm{H}$ atoms were introduced at calculated positions $(\mathrm{C}-\mathrm{H}$ distances $0.93-0.98 \AA$, depending on atom type) and treated as riding atoms, with displacement parameters 1.2 times the $U_{\text {eq }}$ value of the parent atom.

Data collection: XSCANS (Siemens, 1996). Cell refinement: XSCANS. Data reduction: SHELXTL (Sheldrick, 1995). Program(s) used to solve structure: SHELXS86 (Sheldrick, 1990). Program(s) used to refine structure: SHELXL93 (Sheldrick, 1993). Molecular graphics: SHELXTL. Software used to prepare material for publication: SHELXTL.

The authors are grateful to the Natural Sciences and Engineering Research Council of Canada and FCAR (Québec, Canada) for financial support.

Supplementary data for this paper are available from the IUCr electronic archives (Reference: FR1188). Services for accessing these data are described at the back of the journal.

(C) 1999 International Union of Crystallography

Printed in Great Britain - all rights reserved

\section{References}

Abdallah, H., Grée, R. \& Carrié, R. (1982). Tetrahedron Lett. 23, 503-506.

De Amici, M., De Micheli, C. \& Misani, V. (1990). Tetrahedron, 46, 1975-1986.

Mzengeza, S. \& Whitney, R. A. (1988). J. Org. Chem. 53, 4074-4081.

Sheldrick, G. M. (1990). Acta Cryst. A46, 467-473.

Sheldrick, G. M. (1993). SHELXL93. Program for the Refinement of Crystal Structures. University of Göttingen, Germany.

Sheldrick, G. M. (1995). SHELXTL. Structure Determination Programs. Version 5. Siemens Analytical X-ray Instruments Inc., Madison, Wisconsin, USA.

Siemens (1996). XSCANS. X-ray Single Crystal Analysis Software. Version 2.2. Siemens Analytical X-ray Instruments, Inc., Madison, Wisconsin, USA.

Soucy, C., Lacoste, J.-E. \& Breau, L. (1998). Tetrahedron Lett. 39, 9117-9120.

Torsell, K. B. G. (1988). In Nitrile Oxides, Nitrones and Nitronates in Organic Synthesis. New York: VCH.

Wityak, J., Sielecki, T. M., Pinto, D. J., Emmett, G., Sze, J. Y., Liu, J., Tobin, A. E., Wang, S., Jiang, B., Ma, P., Mousa, S. A., Wexler, R. R. \& Olson, R. E. (1997). J. Med. Chem. 40, 50-60, 1292.

Acta Cryst. (1999). C55, 1375-1377

\section{2,3,4,5,6,7-Hexahydro-9,10-dimethoxy-1,2- benzothiazonin-3-one 1,1-dioxide}

\author{
Anthony Linden, Tonya R. Todorova and Heinz \\ HEIMGARTNER
}

Institute of Organic Chemistry, University of Zürich, Winterthurerstrasse 190, CH-8057 Zürich, Switzerland. E-mail: alinden@oci.unizh.ch

(Received 15 April 1999; accepted 3 June 1999)

\begin{abstract}
The amide group in the nine-membered ring of the title compound, $\mathrm{C}_{13} \mathrm{H}_{17} \mathrm{NO}_{5} \mathrm{~S}$, has the trans conformation. The molecules are linked into infinite onedimensional chains by bifurcated intermolecular $\mathrm{N}-$ $\mathrm{H}$... O hydrogen bonds involving the amide $\mathrm{O}$ atom and one of the sulfonyl $O$ atoms of the same neighbouring molecule. The compound was prepared by the Friedel-Crafts acylation of 1,2-dimethoxybenzene and glutaric acid anhydride, followed by reduction of the aryl ketone, esterification, chlorosulfonation, treatment with ammonia, saponification and cyclization of the corresponding 5-(2-sulfamoylphenyl)butanoic acid.
\end{abstract}

\section{Comment}

For several years, we have been studying ring enlargement reactions of $\mathrm{NH}$ acidic heterocycles using 3-amino- $\mathrm{H}$-azirines, (I), as reagents (Heimgartner, 1991). For a successful reaction, the $\mathrm{p} K_{a}$ value of the heterocycle has to be below 8 as the first reaction step 
is the protonation of (I). This requires the heterocyclic $\mathrm{NH}$ group to be flanked by electron-withdrawing groups. One class of compounds which meets this requirement is that of the cyclic sulfonamides (sultams) of type (II). The scope and limitations of this ring enlargement have been established by conducting a series of reactions of (I) with four- to nine-membered oxosulfonamides, (II), in which the corresponding seven- to twelve-membered heterocycles, (III), are obtained as the products (Heimgartner, 1991; Orahovats et al., 1992, 1996; Mihova et al., 1996, 1998; Linden et al., 1998).<smiles>[R]C1([R])N=C1N=[W]</smiles>

(I)

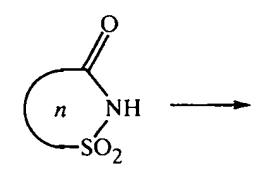

(II)

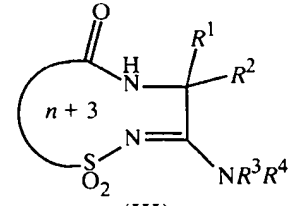

(III)

Some five-membered cyclic oxosulfonamides of type (II) are well known. Saccharin is one example (Fahlberg \& Remsen, 1879; Hettler, 1973) and the crystal structure of saccharin was published by independent workers 30 years ago (Bart, 1968; Okaya, 1969). The molecules are linked into centrosymmetric dimers by intermolecular $\mathrm{N}-\mathrm{H}$. . O hydrogen bonds between the amide groups of adjacent molecules. Similar structures have been found for a four-membered (Mihova et al., 1996) and an eightmembered analogue (Mihova et al., 1998).

Whereas in the case of the four- to seven-membered oxosulfonamides, the ring is built up by treatment of the corresponding sulfonamidocarboxylic acids of type (V) in benzene with $\mathrm{PCl}_{5}$, similar cyclizations to the analogous eight- and nine-membered rings failed (Mihova et al., 1998). A successful ring closure of (V) to give the nine-membered ring in the form of the title compound, (IIa), in $40.1 \%$ yield was performed using diethylphosphoryl cyanide (DEPC) in the presence of ethyldiisopropylamine ( $c f$. Yamada et al., 1973). The analogous eight-membered ring was obtained in $62.4 \%$ yield (Mihova et al., 1998).

The low-temperature structure determination of (II a) shows that the bond lengths and angles have values normally observed in this class of compounds. In contrast to the eight-membered analogue, in which the<smiles>CCOC(=O)Cc1ccc(OC)c(OC)c1</smiles>

(IV)

(a) $\mathrm{HSO}_{3} \mathrm{Cl}, \mathrm{CCl}_{4}, 268-273 \mathrm{~K}$

(b) $\mathrm{NH}_{3}$, dioxane

(c) $\mathrm{KOH} / \mathrm{MeOH} / \mathrm{H}_{2} \mathrm{O}$

(d) $(\mathrm{EtO})_{2} \mathrm{P}(\mathrm{O}) \mathrm{CN}, \mathrm{EtN}\left({ }^{i} \mathrm{Pr}\right)_{2}, \mathrm{CH}_{2} \mathrm{Cl}_{2}$ amide bond has the cis conformation, the conformation about the amide bond $(\mathrm{S} 1-\mathrm{N} 2-\mathrm{C} 3-\mathrm{C} 4)$ of the nine-membered ring in (II $a$ ) lies closer to the trans conformation (Fig. 1). This conformational arrangement means that it is not possible for hydrogen-bonded dimers to exist in the crystal. Instead, the amide $\mathrm{NH}$ group forms bifurcated intermolecular hydrogen bonds, with the amide $\mathrm{O}$ atom and one of the sulfonyl $\mathrm{O}$ atoms of the same neighbouring molecule acting as the acceptor atoms (Table 2). These double hydrogen-bonding bridges link the molecules into infinite one-dimensional chains which run parallel to the [100] direction and each interaction has a unitary graph-set motif of $C(4)$ (Bernstein et al., 1995). The local ring formed by the bifurcated system has a binary graph-set motif of $R_{1}^{2}(6)$.

The nine-membered ring is quite puckered (Table 1) and all ring atoms from $\mathrm{N} 2$ to $\mathrm{C} 6$, inclusive, lie on the same side of the plane of the benzo group. Thus, the overall molecular geometry is sharply angular, with the bend occurring along the $\mathrm{S} 1 \cdots \mathrm{C} 7$ axis. Excluding $\mathrm{C} 8$ and $\mathrm{C} 13$, the mean plane of the ring atoms of the nine-membered ring (r.m.s. deviation $0.435 \AA$ ) makes an angle of $59.69(5)^{\circ}$ with the mean plane of the benzo moiety, the calculation of which includes the coplanar methoxy groups, as well as S1 and C7. The r.m.s. deviation of the constituent atoms from this latter plane is $0.025 \AA$, with a maximum deviation of 0.039 (2) $\AA$ for C14.

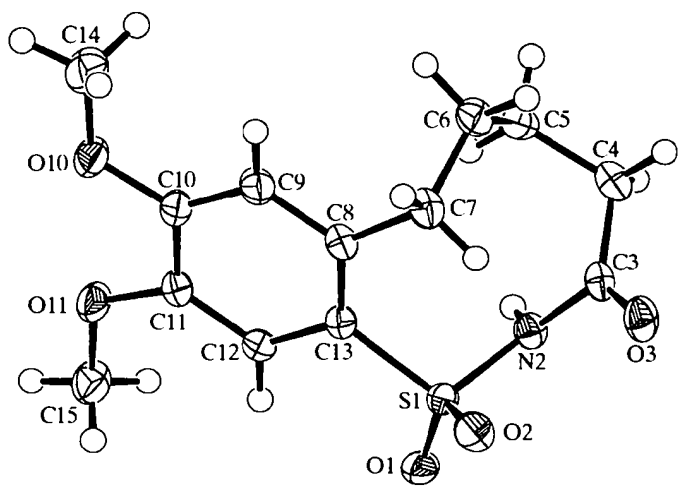

Fig. 1. View of the molecule of (Il $a$ ) showing the atom-labelling scheme. Displacement ellipsoids are drawn at the 50\% probability level and $\mathrm{H}$ atoms are represented by circles of arbitrary size.

\section{Experimental}

The title compound, (II $a$ ), was obtained in $40.1 \%$ yield by stirring a diluted $\left(0.5 \mathrm{mmol} / 50 \mathrm{ml} \mathrm{CH}_{2} \mathrm{Cl}_{2}\right)$ 1:1 mixture of 5-(4,5-dimethoxy-2-sulfamoylphenyl)butanoic acid, (V), and diethylphosphoryl cyanide in the presence of excess ethyl(diisopropyl)amine in dichloromethane at room temperature for $20 \mathrm{~h}$ (Mihova et al., 1998). Chromatographic separation on 
silica gel and recrystallization from dichloromethane-hexane gave colourless tablets (m.p. 464.5-466.5 K).

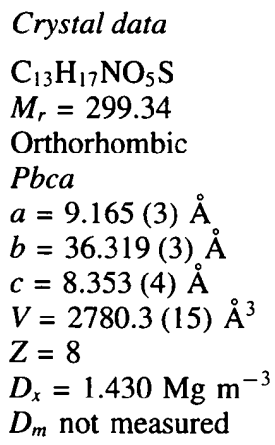

\section{Data collection}

Rigaku AFC-5R diffractometer

$\omega$ scans

Absorption correction: none 4242 measured reflections

3174 independent reflections 2338 reflections with

$$
I>2 \sigma(I)
$$

\section{Refinement}

Refinement on $F^{2}$

$R\left[F^{2}>2 \sigma\left(F^{2}\right)\right]=0.042$

$w R\left(F^{2}\right)=0.115$

$S=1.040$

3174 reflections

187 parameters

$\mathrm{H}$ atoms: see below

$$
\begin{gathered}
w=1 /\left[\sigma^{2}\left(F_{o}^{2}\right)+(0.048 P)^{2}\right. \\
+0.866 P] \\
\text { where } P=\left(F_{o}^{2}+2 F_{c}^{2}\right) / 3
\end{gathered}
$$

$$
\begin{aligned}
& R_{\mathrm{int}}=0.020 \\
& \theta_{\max }=27.5^{\circ} \\
& h=0 \rightarrow 11 \\
& k=-1 \rightarrow 47 \\
& l=-1 \rightarrow 10 \\
& 3 \text { standard reflections } \\
& \text { every } 150 \text { reflections } \\
& \text { intensity decay: none }
\end{aligned}
$$

$(\Delta / \sigma)_{\max }=0.001$

$\Delta \rho_{\max }=0.43 \mathrm{e}^{-3}$

$\Delta \rho_{\min }=-0.37{\mathrm{e} \AA^{-3}}^{-3}$

Extinction correction: none Scattering factors from International Tables for Crystallography (Vol. C)
Data collection: MSC/AFC Diffractometer Control Software (Molecular Structure Corporation, 1991). Cell refinement: MSC/AFC Diffractometer Control Software. Data reduction: TEXSAN (Molecular Structure Corporation, 1997). Program(s) used to solve structure: direct methods SHELXS97 (Sheldrick, 1997a). Program(s) used to refine structure: SHELXL97 (Sheldrick, 1997b). Molecular graphics: ORTEPII (Johnson, 1976). Software used to prepare material for publication: SHELXL97.

The Swiss National Science Foundation and $F$. Hoffmann-La Roche AG, Basel, are thanked for financial support.

Supplementary data for this paper are available from the $\mathrm{IUCr}_{\mathrm{r}}$ electronic archives (Reference: BM1336). Services for accessing these data are described at the back of the journal.
Table 1. Selected geometric parameters $\left(\AA^{\circ},{ }^{\circ}\right)$

$\begin{array}{lclc}\mathrm{S} 1-\mathrm{N} 2 & 1.6500(17) & \mathrm{O} 3-\mathrm{C} 3 & 1.212(2) \\ \mathrm{S} 1-\mathrm{C} 13 & 1.775(2) & \mathrm{N} 2-\mathrm{C} 3 & 1.415(3) \\ \mathrm{C} 13-\mathrm{S} 1-\mathrm{N} 2-\mathrm{C} 3 & 91.83(18) & \mathrm{C} 5-\mathrm{C} 6-\mathrm{C} 7-\mathrm{C} 8 & -60.2(2) \\ \mathrm{S} 1-\mathrm{N} 2-\mathrm{C} 3-\mathrm{O} 3 & 44.7(3) & \mathrm{C} 6-\mathrm{C} 7-\mathrm{C} 8-\mathrm{C} 13 & 108.5(2) \\ \mathrm{S} 1-\mathrm{N} 2-\mathrm{C} 3-\mathrm{C} 4 & -133.63(17) & \mathrm{C} 9-\mathrm{C} 8-\mathrm{C} 13-\mathrm{S} 1 & 178.17(15) \\ \mathrm{N} 2-\mathrm{C} 3-\mathrm{C} 4-\mathrm{C} 5 & 61.3(2) & \mathrm{N} 2-\mathrm{S} 1-\mathrm{C} 13-\mathrm{C} 8 & -60.29(19) \\ \mathrm{C} 3-\mathrm{C} 4-\mathrm{C} 5-\mathrm{C} 6 & 59.8(2) & \mathrm{H} 2-\mathrm{N} 2-\mathrm{C} 3-\mathrm{O} 3 & -167(2) \\ \mathrm{C} 4-\mathrm{C} 5-\mathrm{C} 6-\mathrm{C} 7 & -72.3(2) & & \end{array}$

Table 2. Hydrogen-bonding geometry $\left(\AA,^{\circ}\right)$

$\begin{array}{ccccc}D-H \cdots A & D-\mathrm{H} & \mathrm{H} \cdots A & D \cdots A & D-\mathrm{H} \cdots A \\ \mathrm{~N} 2-\mathrm{H} 2 \cdots \mathrm{O} 2^{\mathrm{i}} & 0.84(2) & 2.09(2) & 2.841(2) & 150(2) \\ \mathrm{N} 2-\mathrm{H} 2 \cdots 3^{\mathrm{i}} & 0.84(2) & 2.47(2) & 3.114(2) & 134(2)\end{array}$

Symmetry code: (i) $\frac{1}{2}+x, y, \frac{1}{2}-z$.

The position of the amide $\mathrm{H}$ atom was refined freely together with an isotropic displacement parameter. Methyl $\mathrm{H}$ atoms were located from a difference Fourier synthesis and were constrained to an ideal geometry with $U_{\text {iso }}(\mathrm{H})=1.5 U_{\text {eq }}(\mathrm{C})$, but were allowed to rotate freely about the $\mathrm{C}-\mathrm{O}$ bonds. The positions of all other $\mathrm{H}$ atoms were geometrically idealized and were refined using a riding model with $U_{\text {iso }}(\mathrm{H})=1.2 U_{\mathrm{cq}}(\mathrm{C})$

\section{References}

Bart, J. C. J. (1968). J. Chem. Soc. B, pp. 376-382.

Bernstein, J., Davis, R. E., Shimoni, L. \& Chang, N.-L. (1995). Angew. Chem. Int. Ed. Engl. 34, 1555-1573.

Fahlberg, C. \& Remsen, I. (1879). Ber. Disch Chem. Ges. 12, 469473.

Heimgartner, H. (1991). Angew. Chem. Int. Ed. Engl. 30, 238-264.

Hettler, H. (1973). Adv. Heterocycl. Chem. 15, 233-276.

Johnson, C. K. (1976). ORTEPII. Report ORNL-5138. Oak Ridge National Laboratory, Tennessee, USA.

Linden, A., Mihova, T. R. \& Heimgartner, H. (1998). Acta Cryst. C54, 1659-1662.

Mihova, T. R., Linden, A. \& Heimgartner, H. (1996). Helv. Chim. Acta, 79, 2067-2074.

Mihova, T. R., Linden, A. \& Heimgartner, H. (1998). Heterocycles, 49, 215-232.

Molecular Structure Corporation (1991). MSC/AFC Diffractometer Control Software. MSC, 3200 Research Forest Drive, The Woodlands, TX 77381, USA.

Molecular Structure Corporation (1997). TEXSAN. Single Crystal Structure Analysis Software. MSC, 3200 Research Forest Drive, The Woodlands, TX 77381, USA

Okaya, Y. (1969). Acta Cryst. B25, 2257-2263.

Orahovats, A. S., Bratovanov, S. S., Linden, A. \& Heimgartner, H. (1996). Helv. Chim. Acta, 79, 1121-1128.

Orahovats, A. S., Linden, A. \& Heimgartner, H. (1992). Helv. Chim. Acta, 75, 2515-2519.

Sheldrick, G. M. (1997a). SHELXS97. Program for the Solution of Crystal Structures. University of Göttingen, Germany.

Sheldrick, G. M. (1997b). SHELXL97. Program for the Refinement of Crystal Structures. University of Göttingen, Germany.

Yamada, S., Kasai, Y. \& Shioiri, T. (1973). Tetrahedron Lett. pp. $1595-1598$ 